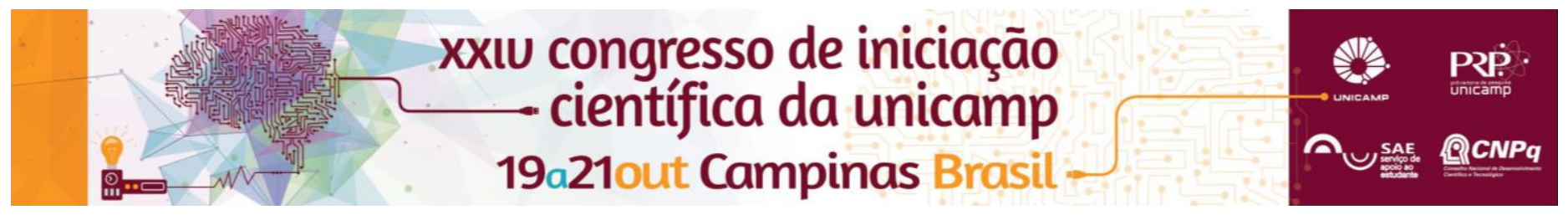

\title{
RASTO ATRÁS: A nostalgia da obra de Jorge Andrade na encenação de Gianni Ratto (1967).
}

\author{
Sofia Fransolin Pires de Almeida*; Orientação: Profa. Dra. Larissa de Oliveira Neves Catalão
}

\section{Resumo}

A pesquisa visa o estudo da primeira encenação de Rasto Atrás, do dramaturgo Jorge Andrade (1922-1984), realizada pelo diretor e encenador Gianni Ratto (1916-2005). A partir da análise da obra escrita, da encenação e de sua repercussão crítica, buscou-se compreender de quais formas as escolhas técnicas e poéticas de Gianni Ratto contribuíram não só para o entendimento dramatúrgico de Rasto Atrás, como também, para a transmissão de características intrínsecas às personagens e ao enredo da peça.

\section{Palavras-chave:}

Jorge Andrade, Gianni Ratto, Relação texto-cena

\section{Introdução}

A pesquisa pretende estudar a primeira montagem da obra de Jorge Andrade Rasto Atrás, encenada em 1967 pelo diretor italiano Gianni Ratto. A partir da junção destes dois materiais, dramaturgia e encenação, se cria uma terceira obra artística, a peça teatral propriamente dita. Dentro deste viés, o objetivo consiste em avaliar como 0 encenador conseguiu trazer para cena o caráter nostálgico que Jorge Andrade carrega na maioria de seus textos. Ou seja, de quais artifícios técnicos e poéticos o diretor se valeu para transmitir a trama de Rasto Atrás, e de que maneiras as subjetividades tão próprias do autor foram transferidas para a direção do espetáculo. Em última instância, a pesquisa almeja compreender o quão bemsucedido foi este primeiro encontro entre texto e cena.

\section{Resultados e Discussão}

Três foram os eixos principais de pesquisa: a leitura e análise de peças teatrais (os dez principais textos de Jorge Andrade, mas também dramaturgias de autores que Ihe serviram de inspiração); a análise dos dados acerca da montagem realizada por Gianni Ratto e sua repercussão, coletados em viagem de campo ao arquivo CEDOC/Funarte no Rio de Janeiro; e, por fim, o estudo de obras teóricas sobre o teatro de Jorge Andrade, 0 teatro brasileiro, e teorias do teatro e do drama.

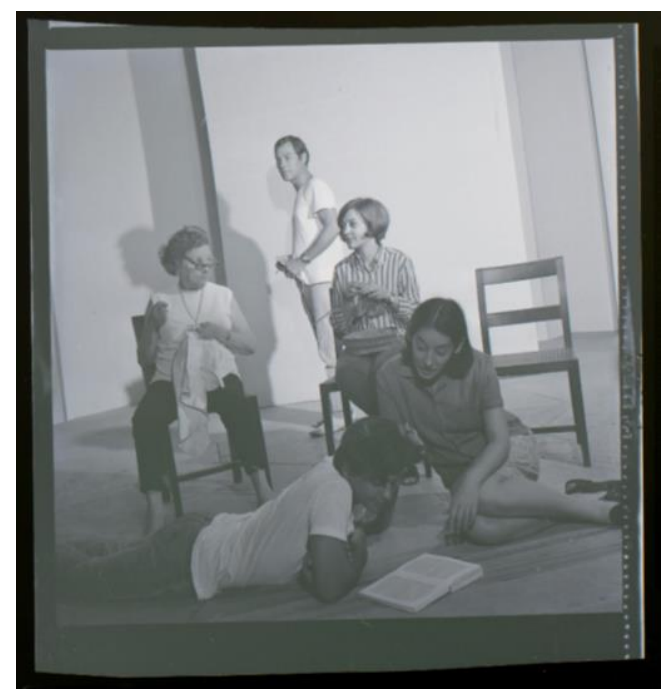

Figura 1: Ensaio de Rasto Atrás. Fonte: CEDOC/Funarte (2016) As informações coletadas na viagem de campo foram extremamente valiosas para a análise texto-cena, uma vez que tomei conhecimento acerca da repercurssão da peça, que foi sucesso de público, provando a boa relação artística entre autor e diretor, que já haviam trabalhado juntos onze anos antes. Porém, o material de maior relevância encontrado nesta pesquisa foi o original da peça Rasto Atrás. Tendo em vista que só existe uma versão pulbicada da peça, que se data de 1970, encontrar o texto que deu origem à primeira montagem tornou a análise da dramaturgia, a compreensão das críticas, e o estudo da encenação muito mais aprofundados.

Por fim, também é interessante mencionar as escolhas técnicas que corroboraram na construção da peça, pois Gianni Ratto se valeu de recursos modernos à época, como a projeção de slides e a utilização de sons para ambientar espaços, de forma que a cenografia de Rasto Atrás contava apenas com telões brancos, cadeiras e uma maquete de árvore. Essas escolhas, além de trazerem avanços para a encenação teatral basileira, contribuiram para a construção de um ambiente simbólico, etéreo, e até mesmo expressionista, caracteristicas presentes na dramaturgia de Andrade e que compõem seu caráter nostálgico.

\section{Conclusões}

O sucesso da primeira encenação de Rasto Atrás foi obtido através da compreensão sensível que Gianni Ratto teve da obra de Andrade. O encenador conseguiu utilizar-se de diferentes recursos para trazer à luz as sutilezas que o texto carrega. Assim como a dramaturgia, por ser muito bem construída, oferece uma base sólida e potente para a criação da cena.

$E$, apesar de alguns críticos da época terem apontado problemas na montagem, tais como: o número de atores, a construção das personagens em cena, os diálogos difíceis que a peça traz, e o excesso de uso de recursos tecnológicos que podiam distrair o público; a resposta positiva dos espectadores e a importância histórica que a montagem carrega provam que as ousadias de Jorge Andrade e Gianni Ratto não foram em vão.

\section{Agradecimentos}

Agradeço à PIBIC, pela aprovação do projeto no ano de 2015.

À Fapesp pela aprovação do projeto no início do ano de 2016 possibilitando a continuidade da pesquisa.

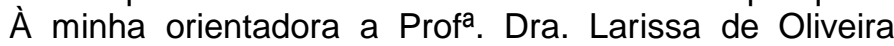
Neves Catalão e ao grupo de pesquisa em dramaturgia Letra \& Ato.

À Jorge Andrade e Gianni Ratto por suas obras artísticas. 